\title{
BM Global Heath Better data for better action: rethinking road injury data in francophone West Africa
}

\author{
Emmanuel Bonnet (D) , ${ }^{1}$ Aude Nikiéma, ${ }^{2}$ Amakoé Adoléhoume, ${ }^{3}$ Valery Ridde (D) ${ }^{4}$
}

To cite: Bonnet E, Nikiéma A, Adoléhoume A, et al. Better data for better action: rethinking road injury data in francophone West Africa. BMJ Global Health 2020;5:e002521. doi:10.1136/ bmjgh-2020-002521

Received 22 March 2020 Revised 8 April 2020 Accepted 8 April 2020

Check for updates

(C) Author(s) (or their employer(s)) 2020. Re-use permitted under CC BY-NC. No commercial re-use. See rights and permissions. Published by BMJ.

${ }^{1}$ Résiliences, Institut de recherche pour le developpement, Bondy, Seine Saint Denis, France ${ }^{2}$ INSS-CNRST, Ouagadougou, Centre, Burkina Faso ${ }^{3}$ LET, IFSTTAR, Marne-la-Vallee, Île-de-France, France ${ }^{4}$ CEPED, Institut de Recherche pour le Développement, Paris, France

Correspondence to Dr Emmanuel Bonnet: emmanuel.bonnet@ird.fr
'Not a single low-income country reduced its road injury rates', said Etienne Krug as the Stockholm Declaration on Road Traffic Safety was adopted during the ministerial conference in February 2020, marking the end of the UN Decade of Action for Road Safety (2011-2020). It reaffirms the global character of road traffic safety which calls for international cooperation and multisector partnerships. ${ }^{1}$ The Decade of Action for 2011-2020 can most importantly be credited with putting the question of road safety at the heart of political agendas and the sustainable development goals (SDGs). However, the results in terms of road traffic mortality are disappointing, particularly in low-income and middle-income countries (LMICs). ${ }^{2}$ The few measures adopted have done nothing to lower the number of injuries and fatalities on the roads, and the situation is still unequal. The average mortality rate is 27.5 per 100000 inhabitants in LMICs, compared with 8.3 per 100000 in high-income countries. Moreover, road traffic accidents are the first cause of death in children and young adults of 5-29 years of age. ${ }^{3}$

The declarations of the major stakeholders of world road safety sought nonetheless to adopt a positive stance with respect to the decade. There is a raft of interpretations of the statistics published by the WHO, asserting that the global rate of deaths has stabilised, at the same time insisting that more should be done to halve the rate within 10 years. The reliability ${ }^{4}$ of these figures is rarely questioned, particularly in LMICs. This question is fundamental, given that if we want to achieve ambitious objectives, we should be able to have an accurate assessment of change in the number of fatalities and injuries. Then again, there are numerous inequalities in the collection of data, and our 10 years of field experience show that in francophone West Africa, for example, there are no data reflecting the reality of the situation. Road safety agencies, established relatively recently (Burkina Faso and Mali: 2009; Niger: 2012), have admittedly created the conditions for standardised data gathering with their Bulletin d'Analyse des Accidents Corporels (BAAC) forms, but completeness, reliability and readiness of the statistics remain debatable.

The WHO has made attempts to correct the current statistics by proposing an estimation allowing for more realistic data. This calculation also remains debatable since it is based on other public data (eg, licensed vehicles, populations), which are also unreliable or too old. In Mali and Burkina Faso, for example, the most recent population censuses are almost 15 years old. ${ }^{3}$ This has resulted in incoherent figures being produced by WHO and refuted by national road safety agencies which are unable to counter with reliable statistics. Stakeholders, however, do agree with the fact that there are too many deaths on African roads. If the next decade aims to achieve its objective, it is necessary first of all to know where these countries stand. Only in these conditions will it be possible to evaluate the initial situations, propose interventions to reduce the rates and finally to evaluate the efficacy of the interventions in the next decade.

This alarming situation relates more to the countries of francophone West Africa which are considered to be those countries with the most worrying situations. ${ }^{5}$ These are also the countries experiencing the fewest interventions, ${ }^{6}$ few research programmes or international support for road safety. The language barrier ${ }^{5}$ presents a major challenge for these countries to access studies published in English. We therefore need in-depth knowledge necessary to identify the problems and put forward solutions, allowing for improvement in generating reliable and comparable data in four principal fields.

First, identify who collects the data, who enters them, who analyses them and under whose authority. In the majority of West African countries, the national police force records 
accidents on the spot, later filling in the $B A A C$ forms present in the whole subregion. ${ }^{78}$ Filling in the sheet is time consuming and certain items are difficult to complete (eg, seriousness of the injury). Most notably, agents are only involved if they are called and this skews the numbers and types of accident recorded. In effect, they intervene in most accidents where there are casualties and substantial material damage. More minor injuries or accidents settled by amicable agreement are therefore excluded from collection and thus from the statistics. The sheets are collected by the road safety agency whose job is to enter the information electronically and generate statistics. Many forms go missing, some are incomplete and manual input takes time. The software used is not common to countries and is often developed by private companies which prevent access to programmed analysis methods. If accidents involve serious casualties, the fire department or ambulance service can intervene; they also create data collection sheets which are archived within departmental structures and are rarely shared. In these countries' hospitals, information is registered in medical records along with the cause of hospitalisation at best, but there is no road trauma registry for victims' after-care. ${ }^{9}$ Detailed health data are therefore not recorded in the $B A A C$ sheets and do not allow for reliable evaluation of mortality after patient care. From the outset, therefore, the very origin of collection is the cause of the data problem in West Africa. ${ }^{10}$ Multiple actors are involved; they generate and collect information but it is not computerised or shared let alone coordinated and approved in order to generate quality statistics.

Second, a clearer definition is needed of the role of road safety agencies in knowing which data to generate. If it is their responsibility to produce statistics in the majority of countries, difficulties remain which are linked to the agencies' ministerial allegiances. They are generally integrated in the Transport Ministries and have no authority over the police officers who fill in the BAAC sheets. ${ }^{11}$ Even if responsibility is given to them at the highest level, they cannot interfere in police force hierarchy. There is no direct link with the health services and they cannot therefore include health data in their reports. Consequently, their motivation to do so is limited and it is therefore a non-priority duty for the agents who collect information. The role of the agencies on the specific question of data collection therefore requires rethinking; it could be entrusted to the rescue and security forces and only the analysis of data with respect to monitoring road statistics entrusted to the agencies.

Third, strengthen multisectorality of road safety in countries. The challenges of the intersectorality of the SDGs at the international level ${ }^{12}$ are indeed also evident at the national level. Despite the existence of interministerial commissions, in practice, each ministry often has a vertical understanding of road safety, with little interaction between ministries. The health sector is therefore rarely associated with intervention in favour of road safety, whereas there are important needs in the whole chain of management and care. ${ }^{13}$ Depending on the country, there are important differences regarding the calculation and cause of mortality between government organisations (hospitals, road safety agencies, police, fire services and so on) and such differences also exist between countries. Strengthening the engagement of the different sectors involved and standardising data collection and indicators between sectors is therefore a matter of urgency.

Fourth, through its regional and national offices, WHO should enhance its involvement in supporting data collection and play a coordinating role, including political dialogue between different government organisations, as it does for Universal Health Coverage. ${ }^{14}$ The current position of using unreliable data and correcting it with modelling based on figures which are themselves inaccurate does not make it possible to generate statistics which are useful for action and decision-making, especially at the country level. One possibility is for WHO to raise awareness and support countries on how to collect data and produce analyses to make all data comparable between themselves and across countries.

Availability of data is fundamental to the production of sound scientific analyses ${ }^{15}$ and to identifying which intervention to implement in countries with a view to achieving objective 3.6 (ie, halve global deaths from road traffic accidents) of the SDGs by $2030 .{ }^{12}$ Awareness and competences exist, but there remains a need for leadership on the question of data generation. Insofar as it is multisectoral, it should be under the responsibility of heads of state and governments. Just like the fight against HIV, should the road safety and the agencies that implement it not be placed under the responsibility of high-ranking government officials so that they make them major security issues? At the beginning of the new decade, the production of reliable figures for a real situational analysis would make it possible to identify intervention targets for each country and to regularly measure their efficacy.

Twitter Emmanuel Bonnet @mavalo76 and Valery Ridde @ValeryRidde

Contributors EB had the initial idea for this paper and wrote the first draft. VR and other authors contributed to the development of ideas. EB and VR wrote the final manuscript. All authors commented on drafts and approved the final version.

Funding The authors have not declared a specific grant for this research from any funding agency in the public, commercial or not-for-profit sectors.

Competing interests None declared.

Patient consent for publication Not required.

Provenance and peer review Not commissioned; internally peer reviewed.

Data availability statement Data may be obtained from a third party and are not publicly available. Due to data sharing agreements, data are unavailable for sharing publicly.

Open access This is an open access article distributed in accordance with the Creative Commons Attribution Non Commercial (CC BY-NC 4.0) license, which permits others to distribute, remix, adapt, build upon this work noncommercially, and license their derivative works on different terms, provided the original work is properly cited, appropriate credit is given, any changes made indicated, and the use is non-commercial. See: http://creativecommons.org/ licenses/by-nc/4.0/.

\section{ORCID iDs}

Emmanuel Bonnet http://orcid.org/0000-0001-6735-5330

Valery Ridde http://orcid.org/0000-0001-9299-8266 


\section{REFERENCES}

1 Hyder AA. Another Summit on global road safety? key questions to ask ministers. Lancet 2020;395:477-9.

2 Banstola A, Mytton J. Cost-Effectiveness of interventions to prevent road traffic injuries in low- and middle-income countries: a literature review. Traffic Inj Prev 2017;18:357-62.

3 Ouedraogo M, Ripama T. Recensement général de la population et de l'habitation de 2006 : état et structure de la population, Burkina Fas. Ministère de l'économie et des finances, Institut National de la Statistique et dela Démographie 2009.

4 Naudet J-D, Jacob J-P. « Les "quignols de l'info". Réflexions sur la fragilité de l'information statistique ", inSciences sociales et coopération en Afrique : Les rendez-vous manqués. Genève: Graduatelnstitute Publications, 2016.

5 Boum Y, Mburu Y. Burden of disease in francophone Africa 19902017: the triple penalty? Lancet Glob Health mars 2020;8:e306-7.

6 Bonnet $\mathrm{E}$, Lechat L, Ridde V. What interventions are required to reduce road traffic injuries in Africa? A scoping review of the literature. PLoS One 2018;13:e0208195.

7 UEMOA, directive $n^{\circ} 14 / 2009 / C M / U E M O A$ portant institution et organisation d'un système d'information sur les accidents de la circulation routière dans les États membres de l'UEMOA 2009.
8 Nassourou A. Rapport Final - Etude sur la sécurité routière au Burkina Faso, 2011. Available: https://www.google.fr/?gws_rd=ssl\# $\mathrm{q}=\mathrm{UEMOA}+$ fiche+BAAC [Accessed 10-oct-2016].

9 Mowafi H, Ngaruiya C, O'Reilly G, et al. Emergency care surveillance and emergency care registries in low-income and middle-income countries: conceptual challenges and future directions for research. BMJ Glob Health 2019;4:e001442. juill.

10 Bonnet E, Nikiéma A, Traoré Z, et al. Technological solutions for an effective health surveillance system for road traffic crashes in Burkina Faso. Glob Health Action 2017;10:1295698.

11 BAD. Étude pour l'amélioration de la sécurité routière dans le District de Bamako. Bamako, 2018.

12 Griggs DJ, Nilsson M, Stevance A, et al. A guide to SDG interactions: From science to implementation. Paris: International Council for Science, 2017.

13 Reynolds TA, Stewart B, Drewett I, et al. The impact of trauma care systems in low- and middle-income countries. Annu Rev Public Health 2017;38:507-32.

14 Robert E, Ridde V, Rajan D, et al. Realist evaluation of the role of the universal health coverage partnership in strengthening policy dialogue for health planning and financing: a protocol. BMJ Open 2019;9:e022345.

15 Bonnet E. Innover dans l'acquisition des données en Afrique. Af Contemp 2016;258:152-3. 